Отримано: 2 грудня 2019 року

Прорецензовано: 9 грудня 2019 року

Прийнято до друку: 11 грудня 2019 року

e-mail: olena.zhygadlo@gmail.com

DOI: $10.25264 / 2519-2558-2019-8(76)-7-10$
Zhyhadlo Olena. Pragmatic features of lawyer-witness interaction in English courtroom discourse. Наукові записки Національного університету «Острозька академія»: серія «Філологія». Острог: Вид-во НаУОА, 2019. Вип. 8(76), грудень. С. 7-10.

УДК: 811.111 '42

Olena Zhyhadlo,

PhD in Philological Sciences

Taras Shevchenko National University of Kyiv

\title{
PRAGMATIC FEATURES OF LAWYER-WITNESS INTERACTION IN ENGLISH COURTROOM DISCOURSE
}

The article focuses on pragmatic features of dialogic interaction of lawyers and witnesses during direct and cross-examination. The lawyer-witness interaction is analysed within the framework of English courtroom discourse, which is a type of institutional discourse. The author summarizes the distinctive features of courtroom discourse, which include emotivity, persuasiveness, competitiveness and asymmetry in terms of power distribution. As a consequence, the speech behavior of professional and lay participants of courtroom talk is predetermined by their function and status at the trial.

Gricean Cooperative Principle has been applied to the study of lawyer-witness interaction in English courtroom discourse. The author has used the methods of discourse analysis and conversational analysis to research the communicative strategies of the participants of examination.

The results show that even though both counsels and witnesses are expected to cooperate in the courtroom, they may flout different conversational maxims. During direct examination, lawyers and witnesses generally comply with the Maxims of Quality and Relevance, while flouting the Maxims of Quantity and Manner. Being cross-examined, witnesses tend to violate the Maxims of Quality, Quantity and Relevance. Lawyers, however, usually comply with the Maxims of Quantity and Relevance, although they appear to flout the Maxim of Quality. The study suggests that complying with or violating a certain conversational maxim, interlocutors pursue certain goals, which are predetermined by the pragmatic situation of examination.

Key words: legal discourse, courtroom discourse, Cooperative Principle, conversational maxims, speech behavior.

\author{
Жигадло Олена Юрї̈вна, \\ кандидат філологічних наук \\ Київський начіональний університет імені Тараса Шевченка
}

\section{ПРАГМАТИЧНІ ОСОБЛИВОСТІ ВЗАЕМОДІї ЮРИСТА Й СВІДКА В АНГЛОМОВНОМУ СУДОВОМУ ДИСКУРСІ}

Стаття присвячена аналізу мовленнєвої поведінки юристів та свідків під час допитів різних видів у суді в світлі приницпу кооперації П. Грайса. Автор висвітлює особливості англомовного судового дискурсу як різновиду інституціонального дискурсу, в якому мовленнєва поведінка учасників обмежена їхньою функиією та статусом в контексті судового засідання. Було встановлено, шо під час прямого та перехресного допитів у суді як юристи, так і свідки здатні порушувати всі чотири комунікативні постулати, щуо обумовлено роллю, яку вони виконують у судi, а також комунікативними стратегіями учасників судового засідання.

Ключові слова: судовий дискурс, юридичний дискурс, принцип кооперації, комунікативні постулати, мовленнєва поведінка.

Introduction. Communicative skills are at the core of legal profession. Examining witnesses and interacting with colleagues in the courtroom, lawyers pursue different goals and adjust speech strategies and tactics to the purposes of the discourse. The speech behavior of lawyers correlates with their objectives as well as the function they perform during the trial and aims to contribute to fairness and justice. The need to analyse the speech behavior of both lawyers and witnesses during their dialogic communication in the courtroom, its pragmatic aims and linguistic manifestations, accounts for the relevance of the research.

The language of law is represented in communication as various models of linguistic interaction where a diversity of linguistic means is employed in a specific context. The study of communicative models employed in the interaction of counsels and witnesses within a larger communicative context of courtroom talk may be possible due to the methods of discourse analysis and conversational analysis.

Analysis of recent publications. Legal discourse has been extensively researched by both Ukrainian and foreign scholars from pragmatic (Atkinson and Drew, Cotterill, Koval, Luchjenbroers, Opeibi, Shevchenko, Zaitseva), psychological and psycholinguistic (Akkermans, Bruinvels, Cuijpers, Elbers, Gudjonsson and van Wees) perspectives. Legal discourse is defined as a type of institutional or ritual discourse, whose aim is to set and regulate social relations of individuals, their performance of social functions and their position in a social structure [2]. Three main criteria: the subject matter, cognitive strategies and purposes determine the distinctive features of legal discourse. The subject matter of legal discourse appears to include material objects, actions and relations, and abstract concepts [ibidem]. In legal discourse material things as well as actions and relations of the participants are evaluated exclusively through the prism of their value in this social practice as objects of law. Abstract concepts are used to name and define the first two categories. However, abstract concepts are not absolute; they tend to be ambiguous and conventional, their interpretation based not on their general scientific meaning, but on the court ruling and the judge's decision.

Courtroom discourse as a variety of legal discourse may be characterised as status and role based, emotive, persuasive, logical and competitive [1, p. 74]. E. Pavlíćková maintains that the language of legal discourse is "a spoken and written medium for exchanging information between/among people participating in various legal situations happening in different legal settings" [9]. The language of law constitutes a special genre of the language with its specific features, distinctive from the language of everyday communication. 
Legal English, with vast borrowings from Latin and French, is characterized by complex syntax, insufficient punctuation, unusual pronouns and set phrases, archaic words, impenetrable technical terms [6, p. 4]. These features seem to make it a difficult task for the lay interlocutor to understand legal English. Being highly formulaic, it differs enormously both in lexis and grammar from everyday English. However, it is not only specific vocabulary and syntax of courtroom talk that is quite challenging for lay participants, but also the interactional and interpersonal rules of courtroom discourse, which are labeled "power-asymmetrical" [4, p.355]. In the hierarchy of courtroom interaction judges and lawyers occupy a more powerful position both legally and linguistically, which places witnesses, who are lay participants, at the bottom of the courtroom hierarchy. This implies that at the trial the latter are at a disadvantage linguistically and under pressure of control and constraint [ibidem].

Due to the fact that language plays a significant role in the courtroom as judicial proceedings including examining witnesses are conducted by means of language, a special branch of applied linguistics, forensic linguistics, which constitutes "an interface between language and the law" [10] has emerged. It is commonly defined as an application of linguistic knowledge and methods to various legal issues [8]. This term was coined in the 1960s by Jan Svartvik, a Swedish linguist who used some linguistic methods of analysis to establish the authorship of statements and the confession of the accused in Evans's case.

The development of forensic linguistics in the United Kingdom pertains to the specific manner of recording of witnesses' statements in the process of interrogation in England. Referred to as Judges' Rules, they prescribed that witnesses' and suspects' statements were to be dictated to and recorded verbatim by a police officer. This fact made the issue of authorship attribution rather questionable. It was due to the involvement of linguistic analysis of incriminating statements that some of the convicts were posthumously pardoned.

Results and discussion. As courtroom discourse is asymmetrical in terms of exercising power by lawyers, with witnesses being at a disadvantage in this unusual environment, application of Grice's Cooperative Principle to the analysis of interrogation techniques for examining witnesses in the courtroom may reveal pragmatic intentions of both professional and lay participants and display how conversational maxims, which are typically applied to the study of casual communication, work in institutional discourse.

Although the aims and intentions of the interlocutors may be different, Gricean Cooperative Principle states that the participants of a conversation should contribute to every stage of it for interaction to continue. In fact, Grice offered a mechanism for decoding information which is not directly stated in the utterance. The Cooperative Principle consists of four Maxims: the Maxims of Quantity (make your contribution as informative as is required; do not make it more informative than is required), Quality (do not say what you believe to be false; do not say that for which you lack adequate evidence), Relation (be relevant) and Manner (avoid obscurity; avoid ambiguity; be brief; be orderly) [5, pp. 77-78].

The study of speech behavior of interrogators and prosecution and defense witnesses during direct and cross-examination in the courtroom revealed the direct correlation between complying with or flouting a certain maxim and the intentions of the interlocutor.

During direct examination, the aim of both the lawyer and the witness is to reconstruct the event, disclose new facts, creating a certain picture for the judge and the jury. In this context the Maxims of Quality and Relation seem to be fulfilled as both the lawyer and the witness tend to contribute to the interaction by means of providing relevant and truthful information. However, they may violate the Maxims of Quantity and Manner. In the process of direct examination the lawyer tries to impose a certain impression on the judge in favour of the message s/he conveys. For this purpose, the interrogator often repeats the facts, paraphrases the witness's statements in order to sum them up or go over them again for the sake of the impact $s /$ he intends to make.

As for witnesses at direct examination, they often contribute more information than is required by the situation in order to seem reliable and trustworthy. The example below contains an excerpt from direct examination of Carl Colby, the neighbor of the victim, by Christopher Darden, the prosecutor in O.J. Simpson's case:

Mr.Darden: Now, directing your attention to the last week of April, 1992, did you have an occasion to call 911 ?

Mr. Colby: Yes, I did.

Mr.Darden: What caused you to call 911 ?

Mr. Colby: Well, it was an evening approximately 10:30 or eleven o'clock at night, and it is a very - it is a residential neighborhood, very quiet, and sometimes before retiring I look-just go check the locks and look around downstairs and make sure the lights are off and things like that. And I happened to look outside and I saw a man outside on the sidewalk.

Mr.Darden: And what was that man doing?

Mr. Colby: Umm, he was standing on the sidewalk looking at what apparently was the residence next door, directly to the north of us.

Mr.Darden: And what time of the night was this?

Mr. Colby: I would say it was approximately between 10:30 and eleven o'clock that night.

Mr.Darden: So the man was standing on the sidewalk?

Mr. Colby: Yes. Initially when I spotted him he was standing about five yards south of the driveway and relatively stationary looking at the house and then since I saw him I was curious and I didn't recognize him, so I thought to myself, what is a man of this description doing outside at that time, so ...

Mr.Darden: So you became curious?

Mr. Colby: Yes, I was curious.

Mr.Darden: Did you continue to watch the man?

Mr. Colby: Yes, I did.

Mr.Darden: What did you see the man do?

Mr. Colby: I saw him observe the residence next door and then walk around the corner, which would be southerly and then westerly on Shetland, and then go back around again and look again at that residence, and I was a little bit concerned because ...

Mr.Darden: Well, let me just stop you there.

In the example below while recollecting the details, the prosecution witness flouts the Maxim of Manner digressing from the train of thought convenient for the counsel. However, the prosecutor interrupts the witness and forces him to stick to the point by means of repeating the same question. 
Mr.Darden: What did you do after you saw the man return to the driveway?

Mr. Colby: I called 911.

Mr.Darden: Why did you call 911 ?

Mr. Colby: Because I felt that the gentleman in question could be a possible burglar or intruder to my residence or to one of the residences in the neighborhood.

Mr.Darden: OK. After you called 911 did you continue to watch the man?

Mr. Colby: Yes, I did, and when I called 911 I told him...

Mr.Darden: When you called 911 did you continue to watch the man?

Mr. Colby: Yes, I did.

Analyzing interrogation techniques of lawyers when cross-examining a hostile witness as well as the responses of witnesses during cross-examination, we arrived at a conclusion that witnesses appear to flout the Maxim of Quantity. They either provide insufficient amount of information or tend to be unnecessarily wordy. They may also resort to providing a number of insufficient and irrelevant details, hence violating the Maxim of Relation, like in the extract below:

Ms. Clark: All right. So you knew that they were talking about a murder investigation on the morning of June the 13th, correct?

Ms. Pilnak: Yes.

Ms. Clark: That's pretty important, isn't it?

Ms. Pilnak: Yes, it is.

Ms. Clark: And you knew that what you said to the police officer would be important, didn't you?

Ms. Pilnak: Yes.

Ms. Clark: And so you were trying to be careful to tell them accurately whatever information you had, weren't you?

Ms. Pilnak: Yes. But I was in shock. I had just found this out minutes before they walked in.

Ms. Clark: All right. Can you answer this? You were talking to the police officers. You knew that your answers to their questions would be important, correct?

Ms. Pilnak: I was in shock. I guess so, but I was in ... I was in shock when they came over.

Non-compliance with these maxims might be interpreted as evading to give the truthful answer in order to conceal certain facts [6]. As regards the interrogators, when cross-examining a witness the lawyer usually fulfils the Maxim of Quantity by means of using simple language, understandable for laypeople. Moreover, it is not advisable for counsels to be too eloquent as it draws attention away from the witness. However, lawyers may flout the Maxim of Quality by means of using prosodic questions, which enable the cross-examiner to disguise new or non-existent facts as the given ones. Since the purpose of cross-examination is to point out the weaknesses in the hostile witness's testimony, to put their truthfulness and credibility to test, or even to discredit a witness [3, p. 142], cross-examiners use this technique to impose their interpretation of the situation on the judge and the jury, like in the extract below which is an excerpt from cross-examination of an expert witness in O.J. Simpson's case.

Mr. Kelberg: And doctor, you said in response to Mr. Shapiro's question that a knife could give the appearance of a cut that you believe was due to glass; is that correct?

Dr. Huizenga: I think there are certain glass cuts that can mimic knife cuts.

Mr. Kelberg: And there are knife cuts that can mimic glass cuts, right?

Dr. Huizenga: I think with a knife, if you're a surgeon, you can mimic a lot of things.

Even though it is usually the lawyer who tends to control and manipulate the hostile witness at cross-examination, exercising his/ her power of turn-taking management, making the witness unfold the facts of the crime in the way which is beneficial for the former, but damaging for the position of the latter, sometimes witnesses may "rebel" against the rules and norms of courtroom interaction and violate the Maxim of Quality challenging the "authority of either legal principles or the individuals who represent them in the courtroom" [4,p. 365].

Mr. Shapiro: At some point in time did you learn that O.J. had said that it wasn't working out with Nicole and that they were going to go their own separate ways?

Mr. Kaelin: At some point, yes.

Mr. Shapiro: Do you recall precisely when that was?

Mr. Kaelin: Gosh, precisely? Not precisely, but ... it could have been March but I can't give you a date.

The example above is quite illustrative as it shows how the defense witness (Mr. Kaelin) resorts to an emphatic phrase to express his contempt having been asked by the prosecutor to recall the exact date of the event which happened several months ago.

Conclusion. Application of Grice's Cooperative Principle and its four Maxims to the analysis of dialogic interaction of lawyers and witnesses in the courtroom might help reveal the pragmatic intentions of both interrogators and witnesses. Even though it may seem that both counsels and witnesses should cooperate in the courtroom to achieve justice, they appear to flout all four conversational maxims. The research proved that conforming to or flouting a certain maxim, interlocutors pursue certain goals, which are predetermined by the pragmatic situation of the examination. Further research may be undertaken to perform quantitative analysis of speech acts of lawyers and witnesses, which violate Grice's maxims during direct and cross-examination.

\section{Література:}

1. Зайцева М.О. Судовий дискурс: мовленнєві стратегії і тактики, мовні засоби вираження конфлікту. Первый независимый научный вестник. № 6, 2016. С. 74-78.

2. Кожемякин Е.А. Юридический дискурс как культурный феномен: структура и смыслообразование. URL: http://konference. siberia-expert.com/publ.

3. Cotsirilos G.J. (1971). Meeting the Prosecution's Case: Tactics and Strategies of Cross-Examination. Journal of Criminal Law and Criminology. 62/2. 141-152.

4. Cotterill J. (2010) Interpersonal Pragmatics. URL: https//books.google.com.ua.

5. Grice P. (1975). Logic and Conversation. Syntax and Semantics. Vol. 3. Speech Acts. New York Academic Press.75-115.

6. Haigh R. (2009). Legal English. London Routledge-Cavendish. 
7. Khoyi A.M., Behnam B. (2014). Discourse of Law: Analysis of Cooperative Principles and Speech Acts in Iranian Law Courts. Asian Journal of Education and e-Learning. $2 / 4$.

8. Olsson J. What is Forensic Linguistics? URL: https://www.thetext.co.uk.

9. Pavlícková E. Legal Writing in Light of Grice's Cooperative Principle. URL: https://www.pulib.sk.

10. Sanni O.O. (2016). The Role of Forensic Linguists in Courtroom Cross-examination. Journal of the Department of English. Obafemi Awolowo University. Ile-Ife. 12/2.

\section{Джерела ілюстративного матеріалу:}

11. https://www.famous-trials.com/simpson 